\title{
PENGARUH BAGI HASIL TERHADAP BIAYA PRODUKSI DAN PENDAPATAN
}

(Studi Kasus Pada Bank Syariah Mandiri Tahun 2016-2018)

\author{
Camelia Rizka Maulida Syukur \\ Universitas Islam Indonesia \\ Email: cameliamaulida13@gmail.com
}

\begin{abstract}
ABSTRAK
Keharaman bunga dalam syariah membawa konsekuensi adanya penghapusan bunga secara mutlak. Teori Profit and Loss Sharing dibangun sebagai tawaran baru di luar sistem bunga yang cenderung tidak mencerminkan keadilan (injustice/dzalim) karena memberikan diskriminasi terhadap pembagian resiko maupun untung bagi para pelaku ekonomi. Bagi hasil dalam akad mudharabah dan musyarakah merupakan pilihan yang tepat dalam pembiayaan maupun pendanaan karena cukup membantu dalam mendongkrak pendapatan perusahaan/lembaga keuangan syariah. Penelitian ini menyajikan data bahwa nilai pendapatan PT Bank Syariah Mandiri mengalami kenaikan selama periode tahun 2016-2018. Seiring dengan hal tersebut, beban usaha juga mengalami kenaikan. Hal tersebut disebabkan terjadinya pula peningkatan pada beban karyawan, beban administrasi dan seluruh item dalam beban PT Bank Syariah Mandiri. Namun, laba usaha PT Bank Syariah Mandiri pada periode yang sama juga mengalami kenaikan bahkan cukup signifikan pada tahun 2018, hingga mencapai 44\%. Hal tersebut juga didukung oleh kenaikan pendapatan pengelolaan dana oleh bank sebagai mudahrib. Implementasi sistem bagi hasil dalam transaksi ekonomi dinilai lebih mencerminkan keadilan dibanding dengan sistem bunga. Artinya, jika suatu perusahaan ingin memiminimalisir biaya dengan jumlah produksi yang sama, maka hendaknya menggunakan sistem bagi hasil. Jika suatu perusahaan ingin memaksimalkan jumlah produksi dengan biaya produksi yang tetap atau sama, maka hendaknya perusahaan menggunakan sistem bagi hasil.
\end{abstract}

Kata kunci: PT Bank Syariah Mandiri, biaya produksi, bagi hasil 


\section{PENDAHULUAN}

Keharaman bunga dalam syariah membawa konsekuensi adanya penghapusan bunga secara mutlak. Teori Profit and Loss Sharing dibentuk guna menjadi solusi dari system bunga yang selama ini menjerat dan tidak menciptakan kemashlahatan ummat. Hal tersebut disebabkan karena adanya ketidakadilan atas pembagian risiko ataupun keuntungan bagi para pelaku ekonomi. Prinsip-prinsip keuangan Islam berdiri atas dasar adanya pengharaman riba, larangan gharar dan maysir, anjuran untuk berbisnis halal, risiko bisinis ditanggung bersama serta kegiatan ekonomi yang berdasar pada pemenuhan keadilan. Profit and loss sharing bermakna bahwa jika dalam kegiatan ekonomi (bisnis) terjadi keuntungan atau kerugian, maka ditanggung bersama. Dalam nisbah bagi hasil tidak dikenal istilah fixed and certain return seperti dalam sistem bunga, tetapi menggunakan profit and loss sharing berdasar pada produktifitas nyata dari kegiatan tersebut ${ }^{1}$.

Sebuah organisasi ataupun institusi merupakan wadah bagi manusia dalam menjalankan fungsinya sebagai khalifah di muka bumi ini. Hal ini nampaknya telah disadari oleh para pelaku organisasi akan tujuan organisasi itu sendiri. Seperti yang diketahui bahwa sebuah organisasi tidak akan berjalan sesuai visi dan misi yang dirancang tanpa adanya keseimbangan antara modal manusia (capital modal) dan

${ }^{1}$ Muchlis Dan Edy Yusuf Agunggunanto Yahya, "Teori Bagi Hasil (Profit And Loss Sharing) Dan Perbbankan Syariah Dalam Ekonomi Syariah," Urnal Dinamika Ekonomi Pembangunan 1, No. 1 (2011): 65-73. modal organisasi (organizational capital). Keduanya harus berjalan beriringan dan tidak bisa dipisahkan. Karena pada hakekatnya sumber daya manusia yang dimiliki perusahaan akan meningkat produktivitasnya karena adanya dukungan anggaran perusahaan. Sebaliknya, jika perusahaan hanya memiliki modal (dana) tanpa adanya SDM, maka roda kehidupan perusahaan tidak akan berjalan sesuai visi dan misi yang dimiliki perusahaan/organisasi. Bukan hanya faktor internal saja, namun juga faktor eksternal sangat berpengaruh bagi eksistensi perusahaan. Faktor eksternal tersebut misalnya lingkungan sekitar dan juga pelanggan. Ada tiga faktor yang dapat mempengaruhi laba perusahaan yaitu biaya, harga jual dan volume penjualan atau produksi ${ }^{2}$.

Dari beberapa faktor tersebut, biaya produksi merupakan salah satu faktor yang mempengaruhi besar kecilnya laba. Biaya produksi merupakan biaya-biaya yang terjadi untuk mengolah bahan baku menjadi produk jadi yang siap untuk dijual. Biaya ini terdiri dari biaya bahan baku, biaya tenaga kerja langsung dan biaya overhead pabrik. Biaya produksi menjadi penentu besarnya harga jual dari suatu produk atau jasa yang nantinya akan mempengaruhi besarnya laba yang diperoleh ${ }^{3}$.

Perbankan merupakan lembaga keuangan yang berpengaruh dalam

\footnotetext{
${ }^{2}$ Mukhlishotul Jannah, "Analisis Pengaruh Biaya Produksi Dan Tingkat Penjualan Terhadap Laba Kotor," Jurnal Banquesyar'i 4, No. 1 (2018): 87112.

${ }^{3}$ Ibid., 88.
} 
perkembangan ekonomi suatu Negara. Secara prinsip, bank konvensional dan bank syari'ah memiliki kesamaan yakni merupakan lembaga keuangan dengan tujuan penghimpunan dana dari masyarakat kemudian menyalurkannya kepada masyarakat pula. Tetapi, dalam operasioanlanya perbankan konvensional menjalankan transaksinya dengan menggunakan sistem bunga sedang perbankan syari'ah menggunakan sistem bagi hasil (bebas bunga) sehingga tingkat suku bunga tidak dapat mempengaruhinya. Di Indonesia, perbankan syari'ah lahir sejak disahkannya Undang-Undang Nomor 7 tahun 1992 tentang perbankan. Adanya payung hukum tersebut menjadi cambuk bagi perbankan syari'ah untuk terus berkembang dan berekspansi. Peraturan terkait perbankan syari'ah kemudian disempurnakan dengan ditetapkannya Undang-Undang Nomor 10 tahun 1998 sampai pada Undang-Undang Nomor 21 tahun 2008 tentang Perbankan Syari'ah yang berlaku hingga saat ini.

Sejak adanya payung hukum tersebut, seiring lahir dan berkembang pesatnya industri keuangan perbankan berbasis syari'ah, salah satunya Bank Mandiri Syariah. PT Bank Syariah Mandiri mulai beroperasi sejak Senin tanggal 25 Rajab $1420 \mathrm{H}$ atau tanggal 1 November 1999. PT Bank Syariah Mandiri hadir dan tampil dengan harmonisasi idealisme industri dengan mengutamakan nilai-nilai keislaman. Bank Syariah Mandiri kemudian tumbuh sebagai lembaga perbankan yang mampu mengkolaborasikan keduanya dan menjadi landasan operasionalnya. Harmonisasi idealisme industri dan nilai-nilai keislaman tersebut yang menjadi salah satu keunggulan Bank Syariah Mandiri dalam kiprahnya di industri keuangan perbankan di Indonesia. Pada Desember 2017 Bank Syariah Mandiri telah mempunyai 737 kantor layanan di seluruh Indonesia dengan akses lebih dari 196.000 jaringan ATM.

Bentuk-bentuk kontrak kerjasama bagi hasil dalam lembaga keuangan syariah secara umum dapat dilakukan dalam empat akad, yaitu musyarakah, mudharabah, muzara'ah dan musaqah. Namun, dalam penerapannya, prinsip yang digunakan pada sistem bagi hasil, umumnya menggunakan kontrak kerjasama pada akad musyarakah dan $m u d h a r a b a h^{4}$. Mudharabah yaitu sebuah akad kerja sama yang dilakukan oleh dua pihak di mana salah satu pihak bertindak sebagai shohibul maal (pemilik modal) dan pihak lainnya bertindak sebagai mudharib (pelaksana usaha). Dalam perbankan syari'ah, akad mudharabah digunakan untuk produk pembiayaan dan pendanaan. Nasabah produk pendanaan akan mendapatkan bagi hasil dari pendapatan bank sesuai kesepakatan nisbah bagi hasil di awal. Sementara nasabah produk pembiayaan mendapat bagi hasil dari keuntungan bank sesuai dengan kesepakatan di awal.

Aplikasi perusahaan berbasis syari'ah memakai sistem sistem profit sharing maupun revenue sharing bergantung pada kebijakan perusahaan tersendiri dalam

\footnotetext{
${ }^{4}$ Muhammad Kamal Zubair, "Mekanisme Bagi Hasil Pada Lembaga Keuangan Mikro Syariah," Inferensi, Jurnal Penelitian Sosial Keagamaan 5, No. 1 (2011): $41-51$.
} 
penggunaan salah satu dari kedua sistem tersebut. Sebuah perusahaan yang memilih sistem profit sharing bagi hasil dihitung dari pendapatan bersih perusahaan setelah dikurangi biaya operasional, oleh karenanya sangat memungkinkan shohibul maal menerima bagi hasil akan semakin kecil sehingga juga akan berimbas ketika ternyata saat itu tingak suku bunga pasar lebih tinggi. Keadaan tersebut akan berpengaruh pada turunnya keinginan masyarakat untuk menginvestasikan dananya pada perusahaan berbasis syari'ah yang berdampak pula pada turunnya jumlah dana pihak ketiga secara umum. Namun ketika perusahaan tetap ingin mempertahankan sistem profit sharing dalam perhitungan bagi hasilnya, maka untuk menghindari risiko di atas perusahaan wajib mengalokasikan sebagian pendapatan dari bagi hasil yang diterima untuk subsidi bagi hasil yang akan dibagikan kepada shohibul maal ${ }^{5}$.

Terlepas dari beberapa informasi di atas, tidak dapat dipungkiri bahwa modal merupakan hal yang berperan cukup vital bagi suatu perusahaan. Dalam analisis biaya, faktor penggunaan modal menjadi sorotan penting karena pada kenyataannya terdapat beberapa sumber modal yang dipakai produsen, sedangkan karakteristik biaya modal bergantung dari sumber penggunaan modal tersebut. Layaknya pengggunaan sumber modal yang berbasis bunga pasti

\footnotetext{
${ }^{5}$ Hardiwinoto, "Analisis Komparasi Revenew And Profit Sharing Pada Sistem Mudharabah Pada Pt. Bprs Pnm Binama Semarang (Kesesuaian Dengan Fatwa Dsn No. 15/Dsn-Mui/Ix/2000 Tentang Prinsip Bagi Hasil Usaha Dalam Lembaga Keuangan Syariah)," Value Added: Majalah Ekonomi Dan Bisnis 7, No. 2 (2011): 46-67.
}

berbeda dengan sumber modal yang berbasis syirkah atau qardun hasan ${ }^{6}$.

Dalam memproduksi barang/jasa pasti sebuah perusahaan akan mengeluarkan biaya, biaya yang dipergunakan dan dialokasikan untuk kegiatan produksi selanjutnya disebut biaya produksi. Dalam pembahasan analisis biaya, faktor penggunaan modal menjadi perhatian karena dalam kenyataannya ada beberapa sumber modal yang digunakan oleh produsen. Oleh karena itu, dalam beberapa waktu ini telah dilakukan pengkajian terhadap dampak syirkah. Sehingga rumusan masalah dalam makalah yaitu: apakah pengenaan bagi hasil terhadap modal akan membawa dampak yang luas bagi tingkat efisiensi produksi?

Penelitian ini dilaksanakan pada perbankan syariah, yakni PT Bank Syariah Mandiri pada tahun 2016-2018. Tahun keuangan 2016-2018 dipilih dengan pertimbangan pada tahun-tahun tersebut perusahaan mengalami peningkatan yang cukup pesat dari sisi profitabilitas perusahaan dibanding tahun sebelumnya. Pada tahun sebelumnya, telah ada penelitian hal yang sama sehingga saat ini peneliti mencoba meneruskan penelitian sebelumnya. Selain itu, karena peneliti ingin mengukur dampak bagi hasil terhadap biaya produksi perusahaan, maka penelitian ini merupakan penelitian studi kasus pada perusahaan perbankan syari'ah.

Sumber data adalah data sekunder eksternal yang diperoleh peneliti secara tidak langsung melalui perantara, seperti

\footnotetext{
${ }^{6}$ Adiwarman A. Karim, Ekonomi Mikro Islam, 5th Ed. (Jakarta: Pt Rajagrafindo Persada, 2012).
} 
orang lain atau dokumen ${ }^{7}$. Data yang diambil terdiri dari laporan auditor independen yang merupakan data kualitatif dan laporan keuangan (laporan hasil usaha dan laporan laba rugi) perusahaan yang merupakan data kuantitatif. Data laporan keuangan auditan yang dianalisis dalam penelitian ini diperoleh situs website resmi perusahaan.

Populasi dalam penelitian ini adalah seluruh perusahaan perbankan syariah yang cukup profitable periode tahun 2016-2018. Sampel penelitian dipilih berdasarkan metode non-probabilitas dengan kriteria tertentu. Sampel diambil secara berpasangan antara kategori perusahaan asuransi jiwa syariah. Analisis data yang digunakan adalah analisis biaya di mana dalam melihat dan melakukan analisis produksi, biaya produksi di analisis dalam dua waktu yaitu jangka pendek dan jangka panjang. Dalam pemahaman ini jangka pendek diartikan sebagai waktu di mana perusahaan dapat menambah salah satu faktor produksi yang digunakan dalam proses produksi. Adapun jangka panjang adalah waktu di mana semua faktor produksi dapat mengalami perubahan (penyusutan maupun penambahan) jumlah. Sedangkan secara keseluruhan biaya produksi (biaya total) yang dikeluarkan oleh produsen dibagi menjadi dua bagian yaitu variable cost (biaya variabel) dan fixed cost (biaya tetap) ${ }^{8}$.

${ }^{7}$ Sugiyono, Metodelogi Penelitian Kuantitatif, Kualitatif Dan $R \& D$, 22nd Ed. (Bandung: Alfabeta, 2013).

${ }^{8}$ Sumar'in, Ekonomi Islam: Sebuah Pendekatan Ekonomi Mikro Perspektif Islam (Yogyakarta: Graha Ilmu, 2013).

\section{BAGI HASIL TERHADAP BIAYA PRODUKSI DAN PENDAPATAN}

Suatu perusahaan yang memilih sistem bagi hasil berdasar revenue sharing yakni bagi hasil yang akan dibagikan dihitung dari total revenue perusahaan sebelum dikurangi dengan biaya operasional, maka dimungkinkan terjadinya bagi hasil yang diterima oleh shohibul maal lebih tinggi dibanding dengan tingkat suku bunga pasar yang berlaku. Keadaaan demikian akan berpengaruh pada keinginan para shohibul maal agar mengalokasikan dananya kepada perusahaan syari'ah di mana mampu memberikan bagi hasil yang maksimal. Hal demikian juga tentunya akan berdampak pada peningkatan jumlah dana pihak ketiga dalam perusahaan syari'ah tersebut. Percepatan tumbuhnya dana pihak ketiga harus diimbangi dengan penyalurannya dalam bermacam produk keuangan sehingga memberi tingkat profitabilitas yang optimal bagi shohibul maal ${ }^{9}$.

Sistem revenue sharing digunakan berdasar pada pendapat Imam Syafi'i yang mengatakan bahwa mudharib dilarang menggunakan dana mudharabah sebagai biaya operasional sebagai suatu nafkah dari harta tersebut baik saat menetap ataupun bepergian karena mudharib telah mendapat porsi keuntungan lebih besar dibandingkan shohibul maal. Sedangkan profit sharing

\footnotetext{
${ }^{9}$ Hardiwinoto, "Analisis Komparasi Revenew And Profit Sharing Pada Sistem Mudharabah Pada Pt. Bprs Pnm Binama Semarang (Kesesuaian Dengan Fatwa Dsn No. 15/Dsn-Mui/Ix/2000 Tentang Prinsip Bagi Hasil Usaha Dalam Lembaga Keuangan Syariah).", 49.
} 
digunakan berdasar pada pendapat $\mathrm{Abu}$ Hanifah, Malik dan Zaidiyah yang mengatakan bahwa mudharib boleht memakai dana mudharabah untuk perdagangan diperjalanan sekalipun untuk biaya nafkah. Hanbali mengatakan bahwa mudharib boleh menafkahkan sebagian harta mudharabah baik dalam keadaan menetap ataupun bepergian dengan seijin shahibul maal, namun besarnya nafkah yang boleh dipakai berdasar pada besarnya nafkah yang telah dikenal (menurut 'urf) para pedagang dan tidak boros ${ }^{10}$.

Selain bersepakat terkait nisbah bagi hasil, mudharib dan shohibul maal juga wajib menyepakati pihak yang akan menanggung biaya lain-lain. Boleh saja disepakati bahwa biaya ditanggung oleh mudharib atau shohibul maal. Jika biaya ditanggung oleh mudharib, maka disebut bagi penerimaan (revenue sharing). Sedang ketika biaya ditanggung shohibul maal, maka disebut bagi untung (profit sharing) ${ }^{11}$. Dalam mu'amalat Islam, sebenarnya akad mudharabah merupakan salah satu bentuk dari akad musyarakah. Bila dalam akad mudharabah ditentukan bahwa penyertaan si pelaksana harus nihil, sehingga penyertaan sipemodal harus 100\%, maka dalam akad musyarakah tidak ditentukan seperti itu sehingga yang terjadi adalah penyertaan dari dua orang pemodal ${ }^{12}$.

Jika membahas terkait perhitungan harga pokok produksi bagi perusahaan jasa saat ini masih menimbulkan perdebatan, karena perusahaan jasa berbeda dari

\footnotetext{
${ }^{10}$ Ibid., 50.

${ }^{11}$ Karim, Ekonomi Mikro Islam., 143.

${ }^{12}$ Ibid., 144.
}

perusahaan manufaktur dan perusahaan dagang. Perbedaan tersebut terlihat jelas dari tidak adanya persediaan barang dagangan dan barang yang siap untuk dijual. Jasa adalah produk non fisik dan tidak berwujud yang dihasilkan dari suatu proses yang dimulai dari pesanan dan berakhir dengan diterimanya jasa oleh pelanggan. Penetapan metode perhitungan harga pokok produksi apakah menggunakan metode full costing atau variable costing berpengaruh terhadap pelaporan laba dan rugi perusahaan ${ }^{13}$.

Sebagaimana dijelaskan sebelumnya, bahwa ada tiga faktor yang dapat mempengaruhi laba perusahaan yaitu biaya, harga jual dan volume penjualan atau produksi. Dari beberapa faktor tersebut, biaya produksi merupakan salah satu faktor yang mempengaruhi besar kecilnya laba. Berikut disajikan data total pendapatan, beban usaha dan laba bersih PT Bank Syariah Mandiri periode tahun 2016 sampai dengan 2018:

\begin{tabular}{|l|c|c|c|}
\hline & $\mathbf{2 0 1 6}$ & $\mathbf{2 0 1 7}$ & $\mathbf{2 0 1 8}$ \\
\hline $\begin{array}{l}\text { Pendapatan } \\
\text { pengelolaan } \\
\text { dana oleh } \\
\text { Bank } \\
\text { sebagai } \\
\text { Mudharib }\end{array}$ & 6.467 .897 & 7.286 .674 & 7.688 .793 \\
\hline $\begin{array}{l}\text { Beban } \\
\text { usaha }\end{array}$ & 4.545 .261 & 5.218 .590 & 5.315 .944 \\
\hline Laba usaha & 442.987 & 470.206 & 839.990 \\
\hline
\end{tabular}

\footnotetext{
${ }^{13}$ Sri Suharti, "Perhitungan Harga Pokok Produksi Perusahaan Jasa Kurir Studi Kasus Pt Pos Indonesia ( Persero )" 1, No. 1 (2016): 72-82.
} 
Tabel 1.1 Total pendapatan, beban usaha, dan laba usaha PT Bank Syariah Mandiri periode 2016-2018 (dalam jutaan rupiah)

Jika dilihat dari tabel yang disajikan di atas, maka nilai pendapatan PT Bank Syariah Mandiri mengalami kenaikan selama periode tersebut. Seiring dengan hal tersebut, beban usaha juga mengalami kenaikan. Hal tersebut disebabkan terjadinya pula peningkatan pada beban karyawan, beban administrasi dan seluruh item dalam beban PT Bank Syariah Mandiri. Namun, laba usaha PT Bank Syariah Mandiri pada periode yang sama juga mengalami kenaikan bahkan cukup signifikan pada tahun 2018, hingga mencapai 44\%. Hal tersebut juga didukung oleh kenaikan pendapatan pengelolaan dana oleh bank sebagai mudahrib. Bagi hasil dalam akad mudharabah dan musyarakah merupakan pilihan yang tepat dalam pembiayaan maupun pendanaan karena cukup membantu dalam mendongkrak pendapatan perusahaan/lembaga keuangan syariah.

Implementasi sistem dinilai lebih berkeadilan dibanding dengan instumen bunga. Bagi hasil melihat kemungkinan keuntungan dan risiko sebagai kejadian yang memungkinkan terjadi suatu hari nanti. Sedang bunga hanya memandang kepastian keuntungan atas pemakaian uang. Bagi hasil ialah roda dasar penggerak operasional dalam bank syari'ah. Sistem profit and loss sharing member kepastian bahwa pendistribusian kesejahteraan lebih setara serta menciptakan kesejahteraan tambahan bagi para pemiliknya ${ }^{14}$. Sistem tersebut dinilai sangat efektif dalam mengurangi bahkan menuntaskan praktik ketidakadilan dan pemerosotan kesejahteraan seperti di bawah sistem bunga. Sistem profit and loss sharing dimungkinkan juga mampu meningkatkan laju investasi dan juga dapat menciptakan lebih banyak lapangan kerja. Sistem bunga hanya membidik proyekproyek yang perkiraan return-nya lebih tinggi dibanding hutangnya, oleh karenanya hal tersebut sebenarnya bisa menjadi alat penyaring proyek-proyek yang bisa diterima perusahaan-perusahaan yang menggunakan sistem bagi hasil. Sistem pembiayaan syari'ah akan mengurangi tingkat spekulasi di pasar keuangan, meski juga tidak menutup kemungkinan pasar sekunder untuk memperdagangkan saham dan sertifikat investasi berdasarkan prinsip nisbah bagi hasil $^{15}$.

Selain keuntungan-keuntungan di atas, ada beberapa rukun dan syarat yang harus dipenuhi oleh kedua pihak agar akad mudharabah menjadi sah secara hukum. Adapaun rukun mudharabah adalah sebagai berikut $^{16}$ :

1. Shahib al-mal (pemilik modal);

2. Mudharib (pengelola);

3. Shighat (ijab dan qobul);

4. Ra's al-mal (modal);

5. Pekerjaan dan keuntungan.

\footnotetext{
${ }^{14}$ Yahya, "Teori Bagi Hasil (Profit And Loss Sharing) Dan Perbbankan Syariah Dalam Ekonomi Syariah.”

${ }^{15}$ Ibid., 71.

${ }^{16}$ Dani Ramdani, "Prinsip Bagi Hasil Dalam Akad Mudharabah Dan Musyarakah Pada Bank Syariah," Aktualita 1, No. 2 (2018): 540-565.
} 
Sedangkan syarat-syarat akad pembiayaan mudharabah adalah:

1. Shohibul maal dan mudharib

a. Shohibul maal dan mudharib wajib cakap hukum dalam bertransaksi sehingga sah secara hukum.

b. Shohibul maal dan mudharib mampu bertindak sebagai wakil dan kafil dari masing-masing pihak.

c. Shigat yang dilakukan bisa secara eksplisit maupun implisit yang menunjukkan tujuan akad.

d. Sah berdasar syarat-syarat yang diajukan dalam penawaran dan akad bisa dilakukan secara lisan atau verbal, secara tertulis ataupun ditandatangani.

2. Ra's al-mal

a. Ra's al-mal harus dinyatakan dengan jelas jumlah dan jenisnya, yaitu mata uang. Apabila ra's al-mal dalam bentuk barang maka barang tersebut harus dihargakan dengan harga semasa mata uang yang beredar (atau sejenisnya).

b. Ra's al-mal harus tunai bukan piutang (namun beberapa ulama' membolehkan ra's al-mal mudharabah berbentuk aset perdagangan, misalnya inventory).

c. Ra's al-mal harus diserahkan kepada mudharib untuk dilakukan usaha.

\section{Keuntungan}

a. Keuntungan harus dibagi untuk shohibul maal dan mudharib.

b. Nisbah keuntungan harus dinyatakan dalam persentase yang mungkin dihasilkan nantinya.

c. Rasio persentase (nisbah) harus dicapai melalui negoisasi dan dituangkan dalam kontrak.

d. Waktu pembagian keuntungan dilakukan setelah mudharib mengembalikan seluruh (atau sebagian) ra's al-mal kepada shahibul mal.

e. Apabila rentan waktu akad mudharabah relatif lama, maka nisbah keuntungan dapat disepakati untuk ditinjau dari waktu ke waktu.

f. Apabila penentuan keuntungan dihitung berdasar keuntungan kotor (gross profit), biaya-biaya yang timbul disepakati oleh kedua belah pihak karena dapat mempengaruhi nilai keuntungan.

4. Pekerjaan

Pekerjaan/usaha perniagaan adalah kontribusi mudharib dalam kontrak mudharabah yang disediakan sebagai pengganti untuk modal yang disediakan oleh shahib al-mal. Dalam konteks ini, pekerjaan berhubungan dengan manajemen kontrak mudharabah. Syarat yang harus dipenuhi adalah usaha perniagaan adalah hak eklusif mudharib tanpa adanya interpensi dari pihak shahib al-mal. Walaupun 
Mazhab Hambali, shahibul maal boleh memberikan kontribusi dalam pekerjaan tersebut.

Selain hal di atas, pembiayaan mudharabah juga memiliki risiko di antaranya ${ }^{17}:$ (1) asymmetric information problem yakni salah satu pihak memiliki kecenderungan lebih tinggi terhadap suatu informasi sehingga berpotensi terjadinya sikap tidak jujur. Oleh karenanya penetapan bagi hasil harus dilaksanakan dengan memperhatikan incentive compatible constraints (batasan-batasan dalam memberi insentif kepada nasabah agar berlaku jujur), (2) side streaming di mana nasabah memakai dana tersebut tidak seperti kesepakatan dalam kontrak, (3) adanya kelalaian dan kesalahan yang disengaja. Dari penjelasan tersebut, beberapa langkah yang diusulkan untuk menentukan alternatif pemecahan masalah itu di antaranya: (1) pertama: penetapan syarat nilai maksimal rasio hutang terhadap modal, (2) kedua: penetapan syarat rasio maksimal aset tetap terhadap total aset, (3) ketiga: penetapan syarat diadakannya monitoring, (4) keempat: penetapan syarat bagi hasil dengan revenue sharing dan (5) kelima: menetapkan syarat preferensi mudharib dengan penetapan penghitungan dan pembayaran zakat. ${ }^{18}$

Cara yang keempat diajukan sebagai alternatif dengan mempertimbangkan bahwa

\footnotetext{
${ }^{17}$ Muhammad Syafi'i Antonio, Bank Syariah Dari Teori Ke Praktek (Jakarta: Gema Insani Pers, 2003).

${ }^{18}$ Friyanto, "Pembiayaan Mudharabah , Risiko Dan Penanganannya ( Studi Kasus Pada Bank Btn Kantor Cabang Syariah Malang )," Jurnal Manajemen Dan Kewirausahaan 15, No. 2 (2013): 113-122.
}

untuk mitigasi risiko, bank syariah dapat melakukan syarat akad untuk pembagian hasil usaha dengan sistem revenue sharing. Pengimplementasian sistem bagi hasil dalam akad mudharabah merupakan salah satu metode dalam perbankan yang harus diperhitungkan. Menurut Sudarsono ${ }^{19}$ satu hal vital dalam perbankan yakni dapat diperhitungkannya hasil pengelolaan modal pembiayaan mudharabah menggunakan dua alternatif yakni: menghitung dari pendapatan produk (revenue sharing) dan perhitungan dari keuntungan produk (profit sharing).

Perhitungan bagi hasil usaha menggunakan model revenue sharing dinilai lebih mudah karena dapat membantu perbankan, salah satunya perbankan tidak perlu petugas dengan spesifikasi khusus terkait suatu bisnis agar dapat mengontrol dan memantau terutama biaya-biaya yang dikelurkan oleh nasabah, namun ternyata tidak semua pembiayaan memakai akad revenue sharing. Menurut Karim $^{20}$ salah satu pedoman umum dalam incentive compatible constrains yakni penetapan syarat agar mudharib berbisnis dengan biaya tidak terkontrolnya rendah (lower fraction of non-controllable cost). Dalam sebuah bisnis mudharib dengan biaya tidak terduganya besar, pasti akan menjadi sumber perselisihan antara shahibul maal dengan mudharib mengenai pihak yang harus menanggung biaya tersebut ${ }^{21}$.

\footnotetext{
${ }^{19}$ Heri Sudarsono, Bank Dan Lembaga Keuangan Syariah (Yogyakarta: Ekonisia, 2003).

${ }^{20}$ Adiwarman A. Karim, Ekonomi Islam Suatu Kajian Kontemporer (Jakarta: Gema Insani Pers, 2001).

${ }^{21}$ Friyanto, "Pembiayaan Mudharabah, Risiko Dan Penanganannya (Studi Kasus Pada Bank Btn Kantor Cabang Syariah Malang ).”, 117.
} 
Data di atas cukup memberikan informasi yang dibutuhkan. Karena sistem bagi hasil mengandung akad-akad di dalamnya, di mana akad-akad tersebut mengandung syarat dan rukun yang harus dipenuhi oleh kedua belah pihak agar akad tersebut sah secara hukum syariah, sehingga memitigasi terjadinya resiko ketidakadilan di kedua belah pihak, sedangkan dalam sistem bunga tidak diatur sedemikian rupa, maka dari sisi mudharib dapat membantu peningkatan pendapatannya. Artinya, jika suatu perusahaan ingin memiminimalisir biaya dengan jumlah produksi yang sama, maka hendaknya menggunakan sistem bagi hasil. Jika suatu perusahaan ingin memaksimalkan jumlah produksi dengan biaya produksi yang tetap atau sama, maka hendaknya perusahaan menggunakan sistem bagi hasil. Kedua hal di atas dapat dijelaskan oleh kurva di bawah ini:

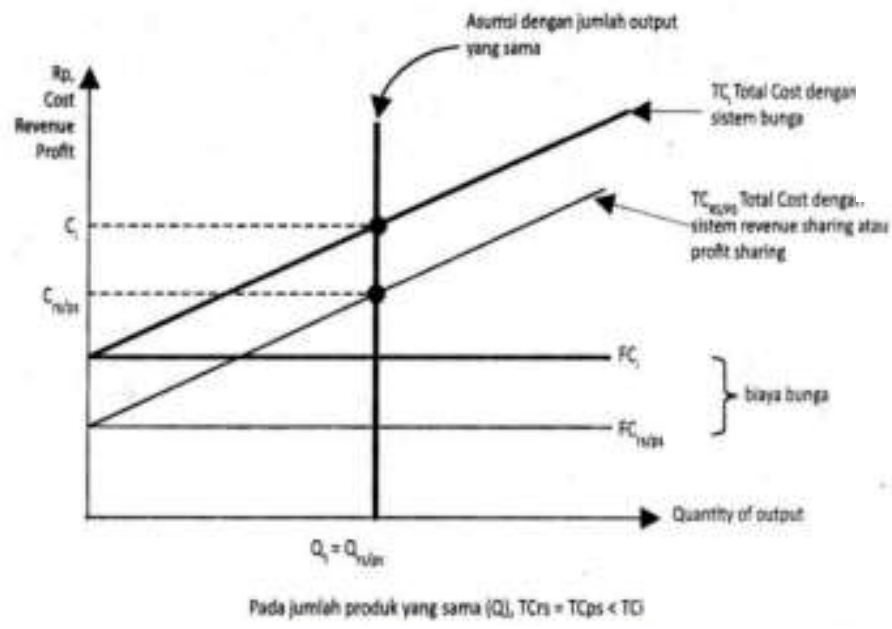

Gambar 1.1 Minimalisasi Biaya untuk Memproduksi Jumlah yang Sama
Untuk menjelaskan hal tersebut, kita menggunakan kurva total cost yang menyajikan perbandingan antara total cost sistem bunga dan total cost bagi hasil. Sebagaimana telah dipaparkan, total cost sistem bunga akan lebih tinggi dibandingkan total cost sistem bagi hasil ${ }^{22}$. Secara grafis, total cost sistem bagi hasil diilusikan dengan TC pada gambar. 1.1 di atas. Sedangkan total cost sistem bunga diilusikan dengan TCi.

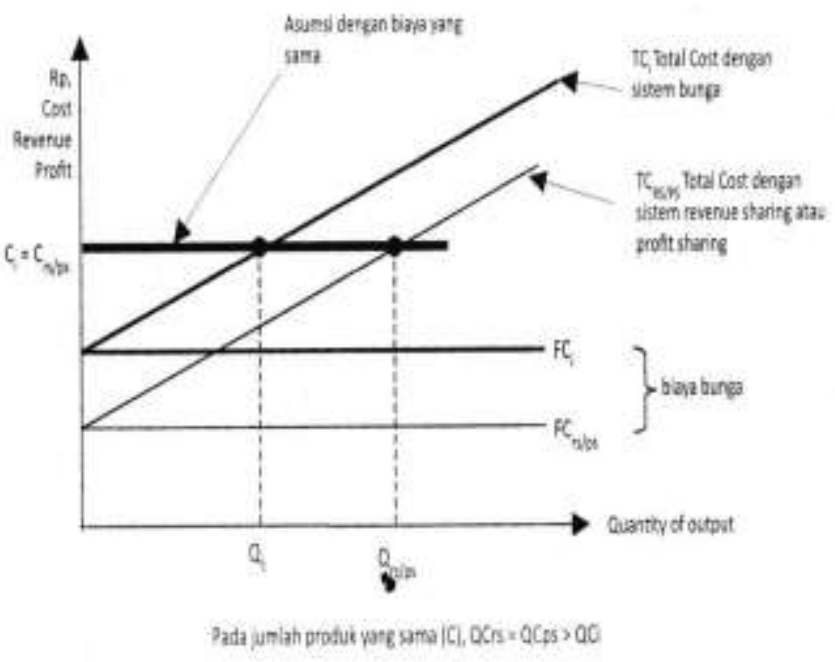

Gambar 1.2 Maksimalisasi Produksi tanpa Kenaikan atau Perubahan Biaya

Untuk menjelaskan hal tersebut, kita menggunakan kurva total cost yang menyajikan perbandingan antara total cost sistem bunga dan total cost bagi hasil. Seperti telah dipaparkan sebelumnya, total cost sistem bunga akan lebih tinggi

\footnotetext{
${ }^{22}$ Karim, Ekonomi Mikro Islam., 145.
} 
dibandingkan total cost sistem bagi hasil ${ }^{23}$. Secara grafis, total cost sistem bagi hasil diilusikan dengan TC pada gambar 1.2 di atas. Sedangkan total cost sistem bunga diilusikan dengan TCi.

\section{KESIMPULAN}

Dari pemaparan di atas, disajikan data bahwa nilai pendapatan PT Bank Syariah Mandiri mengalami kenaikan selama periode tahun 2016-2018. Seiring dengan hal tersebut, beban usaha juga mengalami kenaikan. Hal tersebut disebabkan terjadinya pula peningkatan pada beban karyawan, beban administrasi dan seluruh item dalam beban PT Bank Syariah Mandiri. Namun, laba usaha PT Bank Syariah Mandiri pada periode yang sama juga mengalami kenaikan bahkan cukup signifikan pada tahun 2018, hingga mencapai 44\%. Hal tersebut juga didukung oleh kenaikan pendapatan pengelolaan dana oleh bank sebagai mudahrib. Bagi hasil dalam akad mudharabah dan musyarakah merupakan pilihan yang tepat dalam pembiayaan maupun pendanaan karena cukup membantu dalam mendongkrak pendapatan perusahaan/lembaga keuangan syariah.

Implementasi sistem dinilai lebih berkeadilan dibanding dengan instumen bunga. Bagi hasil melihat kemungkinan keuntungan dan risiko sebagai kejadian yang memungkinkan terjadi suatu hari nanti. Sedang bunga hanya memandang kepastian keuntungan atas pemakaian uang. Bagi hasil ialah roda dasar penggerak operasional

\footnotetext{
${ }^{23}$ Ibid., 146.
}

dalam bank syari'ah. Sistem profit and loss sharing member kepastian bahwa pendistribusian kesejahteraan lebih setara serta menciptakan kesejahteraan tambahan bagi para pemiliknya. Sistem tersebut dinilai sangat efektif dalam mengurangi bahkan menuntaskan praktik ketidakadilan dan pemerosotan kesejahteraan seperti di bawah sistem bunga. Sistem profit and loss sharing dimungkinkan juga mampu meningkatkan laju investasi dan juga dapat menciptakan lebih banyak lapangan kerja. Sistem bunga hanya membidik proyek-proyek yang perkiraan return-nya lebih tinggi dibanding hutangnya, oleh karenanya hal tersebut sebenarnya bisa menjadi alat penyaring proyek-proyek yang bisa diterima perusahaan-perusahaan yang menggunakan sistem bagi hasil. Sistem pembiayaan syari'ah akan mengurangi tingkat spekulasi di pasar keuangan, meski juga tidak menutup kemungkinan pasar sekunder untuk memperdagangkan saham dan sertifikat investasi berdasarkan prinsip nisbah bagi hasil.

\section{DAFTAR PUSTAKA}

Antonio, Muhammad Syafi'i. Bank Syariah Dari Teori Ke Praktek. Jakarta: Gema Insani Pers, 2003.

Friyanto. "PEMBIAYAAN MUDHARABAH , RISIKO DAN PENANGANANNYA ( Studi Kasus Pada Bank BTN Kantor Cabang Syariah Malang )." Jurnal Manajemen dan Kewirausahaan 15, no. 2 (2013): 113-122.

Hardiwinoto. "ANALISIS KOMPARASI 
REVENEW AND PROFIT SHARING PADA SISTEM MUDHARABAH PADA PT. BPRS PNM BINAMA SEMARANG (Kesesuaian Dengan Fatwa DSN No. 15/DSN-MUI/IX/2000 Tentang Prinsip Bagi Hasil Usaha Dalam Lembaga Keuangan Syariah).” Value Added: Majalah Ekonomi dan Bisnis 7, no. 2 (2011): 46-67.

Jannah, Mukhlishotul. "ANALISIS PENGARUH BIAYA PRODUKSI DAN TINGKAT PENJUALAN TERHADAP LABA KOTOR." Jurnal BanqueSyar'i 4, no. 1 (2018): 87-112.

Karim, Adiwarman A. Ekonomi Islam Suatu Kajian Kontemporer. Jakarta: Gema Insani Pers, 2001.

—. Ekonomi Mikro Islam. 5th ed. Jakarta: PT RAJAGRAFINDO PERSADA, 2012.

Ramdani, Dani. "Prinsip Bagi Hasil Dalam Akad Mudharabah Dan Musyarakah Pada Bank Syariah." AKTUALITA 1, no. 2 (2018): 540-565.

Sudarsono, Heri. Bank Dan Lembaga
Keuangan Syariah. Yogyakarta:

Ekonisia, 2003.

Sugiyono. Metodelogi Penelitian Kuantitatif, Kualitatif Dan R\&D. 22nd ed. Bandung: ALFABETA, 2013.

Suharti, Sri. "Perhitungan Harga Pokok Produksi Perusahaan Jasa Kurir Studi Kasus PT Pos Indonesia ( Persero )" 1, no. 1 (2016): 72-82.

Sumar'in. Ekonomi Islam: Sebuah Pendekatan Ekonomi Mikro Perspektif Islam. Yogyakarta: Graha Ilmu, 2013. Yahya, Muchlis dan Edy Yusuf Agunggunanto. "TEORI BAGI HASIL (PROFIT AND LOSS SHARING) DAN PERBBANKAN SYARIAH DALAM EKONOMI SYARIAH." URNAL DINAMIKA EKONOMI PEMBANGUNAN 1, no. 1 (2011): 6573.

Zubair, Muhammad Kamal. "Mekanisme Bagi Hasil Pada Lembaga Keuangan Mikro Syariah.” INFERENSI, Jurnal Penelitian Sosial Keagamaan 5, no. 1 (2011): 41-51. 